\title{
Gezi Assemblages: Embodied Encounters in the Making of an Alternative Space
}

\author{
ÖZNUR KARAKASุ \\ Universitat Oberta de Catalunya, Spain
}

\begin{abstract}
The article aspires to make a claim for the potential of the DeleuzeGuattarian concept of assemblage (agencement) to account for the Occupy Movements in general and 2013 Turkey Gezi Movement in particular. Throughout the article, it is claimed that the concept of agencement provides us with useful tools to elucidate the constitution of a new dissident community in Gezi Park and the subsequent park assemblies. Special emphasis will be put on the capacity of the concept to account for the embodied and embedded nature of the Gezi Movement, an argument further supported by data coming from participatory observations throughout different phases of the mobilization, 23 in depth interviews with activists from different political backgrounds and minutes of the park assemblies. Although the concept of assemblage has started to be used in the analysis of social movements (Bennett, 2005; Chesters \& Welsh, 2006; Lockie 2004; McFarlane, 2009; RodriguezGiralt, 2011, 2015; Rodriguez-Giralt \& Marrero-Guillamón, 2018), not much emphasis is given to the concepts of embodiment and body in assemblages. This article aspires to contribute to the literature by first underlining the importance of embodiment in the Gezi movement and second elucidating it with respect to the concept of body in the original use of the term of assemblage by Deleuze and Guattari (1980).
\end{abstract}

KEYwORDS Occupy Movements; Gezi Movement; assemblage; network; body; embodiment

\section{Introduction}

The national protest known as the Gezi Movement started as an encampment on May $27^{\text {th }} 2013$, when a group of activists from the urban movement networks in Istanbul, who had already been protesting against the AKP government's urban politics, decided to stay at Gezi Park to prevent its demolition as part of the Beyoglu urban transformation plan. This plan envisaged the construction of a commercial and residential complex (Dikeç, 
2017 , p. 206), and the restitution of the artillery barracks that once stood in the whereabouts of the park before the foundation of the republic. It was part of a broader government project that "aimed to radically transform one of the most iconic urban centers in Turkey: Taksim Square" (Kuyumlu, 2013, p. 275), which had long been the center of protests and contentious action in the country.

What started as a "Park Watch" turned into a national uprising against the AKP government's commodification of urban space via urban transformation projects, which were implemented to the detriment of the traditional communitarian bonds that symbolized the mahalle (neighborhood) culture of the urban setting and reflected its increasingly authoritarian rule signified by direct intervention in people's lifestyles (Butler, 2014b; Dikeç, 2017; Farro \& Demirhisar, 2014; Kaynak, 2014; Koç \& Aksu, 2015; Kuyumlu, 2013; Özel, 2014; Özkaynak, Aydın, Ertör-Akyazı \& Ertör, 2015; Tuğal, 2013; Yörük \& Yüksel, 2014). The protests and marches escalated around these grievances and soon expanded across the entire country. The encampment and Park Watch evolved into an occupation once Taksim Square and Gezi Park were "reclaimed" after three days of severe clashes with the police; a growing number of protestors populated the park for 15 days turning the square and the park into what has since then been called the "Taksim Commune." As the name implies, the activists quickly established an alternative form of selfgovernment in the occupied space where basic needs were covered through a donation and solidarity economy. The activists had their own kitchen, health care service for humans and stray animals, childcare services, library, vegetable garden, food and beverage distribution points, and a stage where protesters could express their opinions, as well as hold concerts and theatre shows. The life constituted in Gezi Park was an enacted reaction against the damage done to the ecology of cities by the government's urban transformation projects. The restructuring of the urban setting to promote consumerism and individualism was at odds with the still prevailing urban mahalle culture based on solidarity, and shared and collective use of common space. The latter were the values that constituted the mobilization's symbolic charge, which went hand in hand with a will to have direct participation in the decision-making mechanisms that affected citizens' lives.

With the forceful evacuation of Gezi Park on June $15^{\text {th }}$, a new process was initiated in the Gezi mobilization, as protesters started to make popular assemblies in the parks of their respective neighborhoods. The summer and autumn of 2013 witnessed daily park assemblies in various neighborhoods of the country, where people expressed discontent with the government, organized protest marches and boycotts against supermarkets and shopping malls, and raised their voices to have a say over the decisions in their life spaces, which included "parks, squares, neighborhoods, natural resources, forests, rivers, seas, soil, seeds, public places, artistic spaces" (Marmaris Popular Assembly minutes, July 4, 2013). The Gezi Movement was construed by the protestors as a resistance against an assault on life spaces, 
which went hand in hand with the production of an alternative life space. The basic bodily practices performed to sustain this new life became political in the process of making an alternative space. The production of an alternative space went hand in hand with the production of a new relationality. Basic bodily practices to reproduce an infrastructure that would sustain an alternative relationality paved the way for transformative encounters: production of a new life space where no single opinion rules, and where heterogeneity is possible. As evinced in the literature on the mobilization (Bakıner, 2014; Butler, 2014b; d'Orsi, 2015), the Gezi Movement, as a contentious process, witnessed the creation of a new community out of very disparate components. Gezi communit(ies) did not precede their encounter(s) in the public space, rather they were constituted through the course of the mobilization around common issues regarding defense of life spaces. Notably, deliberative decision-making practices introduced by the autonomous movement networks that had already been active in alterglobalization mobilizations and urban protests became an indispensable part of this defense.

Any account that aspires to elucidate the mobilization requires conceptual tools, first to make a statement about emergence and consolidation of a new collective around deliberative practices, and second, to construe the pertinence of the bodily aspects (affections, interdependency, bodily practices) of the practices that make up the Gezi movement in its totality (Butler, 2011, 2013, 2014a, 2014b; d'Orsi, 2015; Gambetti, 2014;). Lorenzo d'Orsi (2015, p. 17), in his analyses of the Gezi Protests, points to these aspects of the movement:

The Gezi protests, moreover, had a non-teleological trajectory: it materialized in the same moment it was born and was characterized by a sharp aporia. Therefore, the question is not to merely analyze the reasons that led to dissent and grievance. Instead, by shifting the analysis from the why to the how, it is possible to observe new mechanisms triggered by the participation in the movement itself.

D'Orsi's (2015) emphasis on the requirement to shift to the question of how leads him to turn his attention to the lived experience of the movement and embodied practices that sustained the protests in every phase of the mobilization. Similarly, Fatmagül Berktay (2014, p. 8, emphasis added) opened the 2013 Politsci Conference on the Gezi Movement by stating:

In the space of action and freedom symbolized by Gezi Park, individuals gathered together with their differing views and with their concrete bodies marked by difference. Thus, in the contradictory and hybrid space of the 'Gezi agora' they embodied and put into practice this new concept of power.

This emphasis on concrete bodily presence marked by difference and embodied practices is also congruent with the intervention of Zeynep Gambetti (2014), who calls the Gezi Movement "the resistance of a 
multiplicity of bodies," referencing Hardt's definition of multitude: "multitude is not a body in the sense that Hobbes theorized the body politic; it is rather a corporeal assemblage that acts as a living multiplicity" (Gambetti, 2014, p. 98). Here, Gambetti (2014) refers to the concept of a corporeal assemblage that acts as a multiplicity of bodies.

In this article, following Gambetti, I assert that the concept of assemblage (agencement) developed by Deleuze and Guattari (1980) is a valuable tool to account for both of the above concerns: emergence of new dissident communities in the reclaimed public space(s), and embodiment. The concept is already used in social movement studies to conceptualize the emergence of new dissident communities and protest types in the alter-globalization movement and the occupy-like movements (Bennett, 2005; Chester \& Welsh, 2006; Lockie, 2004; McFarlane, 2009). Nevertheless, the bodily and affective character of the concept is yet to be elucidated to relate emergence to embodiment and thus explain the aforementioned bodily aspects of the Gezi Movement specifically, and the Occupy Movement in general. ${ }^{1}$ I thus claim that a direct reference to the concept of assemblage within its larger philosophical background in Deleuze-Guattarian (1980) philosophy highlights that assemblage is always already conceived as a multiplicity of bodies, the latter defined through its capacity to affect other bodies and be affected by them. The political repercussions of the conception of assemblage as body is that becoming, and thus political transformation and social change, are intrinsically related to the making of new spaces and relationalities wherein bodies are endowed with novel capacities to act. Deleuze and Guattari (1980) state that the question of becoming is a question of affect. ${ }^{2}$ Therefore, an affect is both a bodily and mental action that increases or diminishes the capacity of bodies to act, hence their power (Deleuze \& Guattari, 1980, pp. 313-314). Referring to Spinoza in their definition of the body, Deleuze and Guattari (1980, p. 315) state that bodily "affects circulate and transform themselves throughout the assemblage."

Hence, the following aspects come to the fore as political issues to be taken into consideration in Occupy Movements, which rely on creating alternative and highly bodily means to relate to the public space (Protevi, 2009; Estralella \& Jimenez, 2016): the very practices through which bodies are sustained (collective cooking, eating, cleaning, praying); highly performative protest types (Earthmeals, park assemblies, occupation etc.); interdependency among diverse components; visibility of the agency of bodies (a bodily urge

${ }^{1}$ Occupy Movements have been considered by many as a new wave of social movement that has had repercussions in distinct geographies from the USA (Occupy Wall Street), to Europe (Spanish indignados movement, the occupation of Syntagma Square in Athens) and Arab countries (the so-called Arab Spring) (Castells, 2015; della Porto \& Mattoni, 2014; Gerbaudo, 2012; Özel, 2014; Tejerina, Perugorria, Benski \& Langman, 2013; Tuğal 2013; Vatikiosis \& Yörük, 2016). In this article, I follow this insight and situate the Gezi Movement as part of this new wave of social movements.

2 "Affect" derives from a Spinozist term - affectus - to describe changing bodily and mental states through the encounters in which bodies find themselves. 
to take part in a contentious action and bodily exposure therein); and bodily changes and transformation occurring in new encounters in which capacities of bodies to affect and be affected by one another are increased. The Gezi Movement can be seen as an interstice wherein bodily encounters and collective life-making practices among a highly diverse group of protesters amounted to affects of joy, solidarity and care to be circulated throughout the new assemblage of protesters.

We see that the emergence of new dissident communities in the Gezi Movement went hand in hand with all these embodied aspects of the mobilization. In this article, I propose the concept of assemblage as a valuable tool to conceive emergence as embodiment. In what follows, I first explain the use of the concept in the literature of social movement studies. The concept is already in circulation to account for questions around emergence in the new social movements with its emphasis on heterogeneity and "becoming" as a revolutionary practice of transformation. The concept is mobilized in the literature to elucidate the power of social movements to assemble new dissident communities in transformative encounters. I assert that this aspect of the concept also requires a discussion of the role of body in assemblages. Transformation - i.e. "becoming other than one is" Bennett 2005 , p. 44) - in a relational space of encounter is a bodily and affective affair. In the second main section I evoke the embodied and embedded nature of the Gezi Movement using fieldnotes from my participant observations in the Gezi encampment and the Abbasağa and Yoğurtçu Park assemblies in the summer and autumn of 2013. I present a content analysis of 23 in-depth, semi-structured narrative interviews with activists from different political backgrounds, as well as of the minutes of park assemblies compiled on the website, http://parklarbizim.blogspot.com.es. ${ }^{3}$ The article's final section briefly discusses this empirical data in relation to the significance of body in assemblages.

\section{Assemblage in Social Movements Theory}

In the literature on social movement studies, there is a growing interest in using the concept of assemblage, rather than network, to define collective action, as the latter is said to refer to the type of interactive relationality only between stable and fixed entities (Chesters \& Welsh, 2006; Ingold, 2007, 2011; Lockie, 2004; McFarlane, 2009; Rodriguez-Giralt, 2015; RodriguezGiralt \& Marrero-Guillamón, 2018). Although this shift to assemblage is welcome, the current use of the term neglects its capacity to speak to embodiment. In attempting to develop a concept to overcome the abovementioned weakness of the network concept, Colin McFarlane (2009, p. 566)

\footnotetext{
${ }^{3}$ The interviews were conducted in the context of my own positionality as an activist with loose ties to the autonomous movement networks of the city.
} 
coins the term "translocal assemblages" to define "composites of place-based social movements which exchange ideas, knowledge, practices, materials and resources across sites." This, according to McFarlane (2009, p. 566; see also Chesters \& Welsh, 2006), goes beyond the implication of nodes or points suggested by the term "network," in the sense that assemblage, "unlike network.... does more than emphasize a set of connections between sites in that it draws attention to history, labour, materiality and performance. Assemblage points to reassembling and dissembling, to dispersion and transformation, processes that are often overlooked in network accounts." McFarlane aptly emphasizes that the power of the concept of assemblage is to help construe social movements as material, bodily, historical processes that (re)assemble communities in novel constellations. In that sense, according to McFarlane (2009, p. 562), the term assemblage implies "spatiality and temporality... distributed agency, emergence and power as plurality in transformation."

In the philosophy of Deleuze and Guattari (1980), assemnblage refers to a relationship, an ordering (Müller, 2015), "an arrangement or layout of heterogeneous elements" (Nail, 2017, p. 21) between the whole and its parts that does not attribute a transcendental position to the former. The whole has neither logical nor ontological priority over its parts. Each part entering the relational domain transforms the overall relationality, while at the same time being transformed by it. This is "the externality of relations to their terms" (deLanda, 2006, p. 9) that rejects "unity in favor of multiplicity" (Nail, 2017, p. 22). When the relations are considered to be "external" to their terms meaning that they are made up of these terms but cannot be reduced to them - it becomes impossible to attribute qualities or an organizing principle to the whole or the unity that precedes the actual constitution of that particular relational space. An assemblage is therefore an ever-changing, productive, and emerging relationality. While the components involved in an assemblage continue to be active according to their power to affect other components and to be affected by them, neither they nor the whole are "essences" or "substances" that can be defined by their properties prior to their involvement in the assemblage. Hence, assemblages:

....are the result not of an aggregation of the components' own properties but of the actual exercise of their capacities. These capacities do depend on a component's properties but cannot be reduced to them since they involve reference to the properties of other interacting entities." (deLanda, 2006, p. 11)

Given this conceptualization, assemblage is a useful analytical tool to study recent social movements that are composed of heterogeneous components in terms of both the background of protesters and collectives involved therein and their liminal nature at the intersection of the technological (e.g., the savvy use of social media), the corporeal, and the semiotic (e.g., the creation of a common language and identity via online and offline media) registers. More than just an analytical tool to account for social movements, the 
concept of assemblage can aptly be construed as a type of collective action wherein emerging dissident collectives are constantly and horizontally assembled and dissembled through transformative encounters in reclaimed spaces. Indeed, Thomas Nail (2017, pp. 28-33) stresses that everything is an assemblage, yet there are different types: territorial assemblages, state assemblages, capitalist assemblages and nomadic assemblages (also called "war-machines"). Occupy Movement assemblages correspond to warmachines, in that they are concrete assemblages wherein there is no "abstraction and dominance of any part of the assemblage" over any other part" (Nail, 2017, p. 33). The insistence on non-institutional means of making politics, the precedence of horizontal decision-making practices wherein no collective or individual has dominance over others and the prevailing body politics wherein transformation is experienced as a lived experience of 'becoming' specify Occupy Movements. As such they construct "a participatory arrangement in which all the elements of the assemblage enter into an open feedback loop in which the condition, elements and agents all participate equally in the process of transformation." (Nail, 2017, p. 33) Assemblage as war-machine mobilizes becoming. Becoming is always a political issue. The concept of war-machine is developed by Deleuze and Guattari (1980) to construe emergent dissident collectives outside institutional politics and state apparatus (Sibertin-Blanc, 2013, p. 12). Occupy Movements, as such can well be construed as war-machines (Conio, 2015, p. 43).

This capacity of the concept of assemblage as war-machine to explicate emergence and transformation by way of assembling new and disparate components is of utmost importance especially in the conceptualization of the Occupy Movements. These movements are thought to differ from alterglobalization movement networks in the sense that they mobilize larger groups of people who have not been previously involved in existing activist networks. In an article on the USA Occupy Movement, Jeffrey Juris (2012) introduces the term, the logic of aggregation, to define this contagious character of the new wave of contentious action. In distinction from the previous cycle of global justice movements governed by the logic of network among already politicized activists, a logic of aggregation, "which involves the assembling of masses of individuals from diverse backgrounds within physical spaces," (Juris, 2012, p. 260) characterizes the new occupation movements. These new movements, characterized by the occupation of public squares, rely on a logic of aggregation whereby a large number of people are at first aggregated via social media, and then embodied on the streets.

While focusing on online media's importance in the aggregation of larger masses within the public space, Juris neglects to analyze how bodies thus aggregated constitute a new relationality. He does not address the emergence of new dissident communities, or their transformative and interactive character. Assemblage, rather than aggregation, is more suitable to accounting 
for this aspect of mobilization. The contagious quality of assemblages refers to a very bodily, hence affective, interaction of forces that endows bodies with new capacities to affect and be affected.

Large populations swarming public spaces to reclaim their rights over life spaces are not mere aggregates of existing networks of activists. Rather, their very aggregation through contagion makes a new assemblage that reconfigures the ways all components, both existing activist networks and newly aggregated populations, transform each other. Jane Bennett (2005, p. 44 , emphasis added) refers to this characteristic of the assemblage as "the ability of bodies to become otherwise? than they are, to press out of their current configuration and enter into new compositions of self as well as into new alliances and rivalries with others. ${ }^{, 4}$ Hence, the concept of assemblage, rather than aggregation, has the potential to account for the emergence of new dissident collectivities in the Occupy Movements, as it addresses how a new configuration is assembled in heterogeneous encounters and how this configuration implies a bodily, relational scheme of transformation and becoming.

This relational scheme of transformation and becoming, evoked by the question of emergence in social movement studies, further paves the way for dwelling on the lived experience of the movement with an emphasis on body, embodied practices, encounters and affects (Butler, 2011, 2014a,b; d'Orsi, 2015; Gambetti, 2014; Gregory, 2013; Happe, 2015; Perrugorría \& Tejerina, 2013; Protevi, 2015). The concept of assemblage, apart from being a useful tool in construing the composition of heterogeneous terms on a plane of consistency through horizontal, rhizomatic bonds, can also be used to account for the bodi(es) politic (Protevi, 2009) prevailing in the Occupy Movements in general and the Gezi Movement in particular. When we situate the concept of assemblage within the original context developed by Deleuze and Guattari (1980), we see that it also refers to a certain conception of the body that is highly influenced by Spinoza: a body that is defined through its capacity to affect and to be affected by others. Body politics in Deleuze and Guattari refer to the capacity of bodies to undergo encounters in which they are endowed with novel affective capacities to relate to one another. As such, they adopt the Spinozist dictum that we cannot know what bodies can do without knowing about their affects, about the ways they are constituted via the affects of and on their bodies (Deleuze \& Guattari, 1980, p. 314). Politics, in this context, becomes intimately related to encounters wherein bodies are

\footnotetext{
${ }^{4}$ Stengers and Pignarre define it as "becoming-child of the event" (Stengers \& Pignarre, 2005, p.10), which implies a certain modesty of letting oneself be transformed by the event, instead of assuming the position of its spokesperson or prophet. It is indeed "a becoming-other-than-onenow through encounters with difference," in language referring to Direct Social Work's activities during Occupy Slovenia (Razsa \& Kurnik, 2012, P.240). "Occupations materialized people power through a subversion of the 'normal distribution' of police spaces, 'detouring' this spatial logic for political effect" (Bassett, 2014, p. 893), mobilizing a redistribution of the sensible, being the condition of political subjectification.
} 
affected by other bodies and their capacities to act are thus increased. The concept of assemblage accounts for the emergence of new collectivities as embodiment of novel relationalities in which bodies' capacities to act come to the fore and are endowed with new capacities to relate to one another. For this reason, newly assembled bodies are more than mere aggregations; they refer to an active community-making process wherein the body, with its requirements, fragilities and potentials, comes to the fore.

Construing the Gezi Movement as a particular kind of assemblage (i.e., war-machine) might help us elucidate a central yet understudied characteristic of the Occupy Movements: their materiality at the intersection of affective, corporeal, infrastructural, and technological components. It is this materiality that might help us construe the construction of new alliances through which bodies are endowed with new capacities to "become otherwise? than they are" (Bennett 2005, p. 44). My data from different phases of Gezi Protests evince the role of bodily practices, affects, interdependency and encounters in the becoming-activist of large populations swarming Gezi park and park assemblies in the summer and autumn of 2013. Gezi was perceived as a moment when activists discovered new bodily capacities and experienced what their bodies could do under new settings, which had immediate translations in their affective states. Affirmative affects, care and humor, despite the risk brought forward by the "exposure" of bodies in public space, marked life in Gezi (Butler, 2011, 2014a). In an attempt to mobilize the concept of assemblage to account for the body politics in the Gezi Movement, I now draw from interviews and participant observation to outline a narrative of the Gezi Movement that highlights its bodily and embodied character.

\section{Bodies in Dissident Action}

The embodied and material character of the Gezi mobilization involves different axes that are intrinsically related to one another in a way that underlines the priority of bodies in the constitution of Gezi communities throughout the mobilization. In this section I concentrate on four such axes. The first is the significance attributed to the communal reproduction of an alternative life around basic requirements. "[In Gezi], all previously theoretical problems became problems of life itself. It was the realization of the materialism of bodies," stated interview participant Sinem (woman, 34, member of a Marxist-Autonomist organization), as a way to underline the importance attributed to the maintenance of an infrastructure that would sustain an alternative relationality. The encampment in Gezi Park was called the "Taksim Commune" by the protesters, as a way to recognize basic requirements such as food, shelter, and cleaning as political issues around which the new Gezi communit(ies) were constituted. 
When we look at the practices and protest types that constituted the Gezi Movement, we see that they are all performative protests wherein the body and various ways to sustain it come to the fore. Occupation is a bodily protest type that is based on making an alternative life space that would sustain bodies under different relations. The activists all referred to the significance of practices oriented towards daily bodily requirements like food-sharing in the constitution of life in Gezi Park. It is no surprise then that Earthmeals, collective iftar dinners originally introduced by anti-capitalist Muslims to criticize the ostentatious iftars organized by the government, became one of the most significant protest types of the Gezi Movement. ${ }^{5}$ Immediately after the forceful eviction from Gezi Park in June 2013 came the month of Ramadan. Gezi Park and Taksim Square were under police seizure and there were ongoing marches, protests, and clashes with the police in Istiklal Street. The government started organizing luxurious iftar dinners. In response, on July $9^{\text {th }}$ around 15,000 people organized an Earthmeal immediately behind the then almost permanent police barricade at the intersection of Taksim Square and Istiklal Street, facing the evicted Gezi Park. Activists spread newspapers on the street, sat on them, and served food, effectively creating a long line reaching out along Istiklal Street. The activists, whether practicing Muslims or not, joyfully shared their humble food with one another with defiant looks on their faces. We see a similar bodily component in other protest types that have come to define the Gezi Movement. Park assemblies that continued in the summer and fall of 2013 became sites of bodily encounters among protesters from diverse political backgrounds paving the way for bodies to be affected by one another in previously unimaginable ways.

The second axis, which intertwines with the first, involves an acute realization of interdependency and appreciation of heterogeneity as power. As evinced by the literature on the Gezi Movement (Bakıner, 2014; Butler, 2014b; d'Orsi, 2015), heterogeneity and diversity were significant features of Gezi encampment and park assemblies.

The environmentalists found themselves joined by the anti-capitalists, including the anti-capitalist Muslims who did not want that mosque in that place and for that reason; and they in turn were joined by those who demand the public ownership of water rights. In addition, the gay, lesbian and transgender community was significantly represented, occupying public space and demanding the right to do so without fear. The women against sexual harassment in the streets also showed up, clearly finding temporary public safety in a non-violent movement of direct democracy. When the Kurdish mothers arrived, holding the signs emblazoned with images of their "disappeared" sons who had clearly been tortured, killed and disposed of by Turkish army troops, the crowd was apparently aware that something breathtaking was taking place. (Butler, 2014b, p. xi).

\footnotetext{
${ }^{5}$ In Islam, iftar is the dinner following a day of fasting in the month of Ramadan.
} 
Gezi protesters were quick to embrace this heterogeneity as the power of the movement. The minutes of the Ankara 100 Y 1 Park Assembly for June $25^{\text {th }}$ report:

How could LGBT people, people from all political opinions, women and men from all ethnicities come together? What has changed? Before, when women used to take the streets for their rights, men were not there for them. Environmentalists took the streets, they stood alone, etc. From now on, we will be with all those who take the streets for their rights. (Anonymous)

The heterogeneity and diversity of protesters paved the way for an acute realization of inter-dependency. The assembly minutes of Çamlı Park for June $17^{\text {th }}$, just after the evacuation of Gezi Park, quotes an activist as follows: "we have seen that we can have an impact when we collectively do things that we cannot alone accomplish, that's why we are here." There was a common understanding that the strength of the mobilization stemmed from its capacity to incorporate the entire opposition of the country. The feeling that each and every component depended on one another, along with solidarity prevailing in the encampment and barricades against the violent police oppression, resulted in an affective space of inter-dependency.

The third axis involves a bodily urge to participate in the mobilizations. For example, on June $3^{\text {rd }}$ in Taksim Square under a heavy gas cloud above us and constant noise of blast bombs, a young woman approached me and said:

You look like you are experienced in these things. I have never been on the streets before. Can you please tell me whether we would be like Egypt? I am so afraid. I am pretty sure that they will open fire on us, I mean they will kill us. Then I say to myself, whatever, never mind go home, do what you regularly do, but then I cannot sleep, I cannot eat, I cannot stay away from Twitter or Facebook checking what the hell is going on here. I have to be here, I cannot NOT come, do you understand?

Protestors often stated that they were "drawn to the square," and repeatedly reported that they could not remain indifferent to what was happening there. Participants of the Gezi mobilization also emphasized clear changes in their bodily state, referring for example to an accelerated bodily rhythm as well as less requirement to sleep. They stressed the prevalence of positive emotions like hope, joy and care.

Gezi was a moment where bodies, their needs and affects, their power and fragility, came to the fore. On many occasions activists referred to their experiences in Gezi in terms of finding themselves in situations where they did unexpected things. An activist conveyed in an interview the following anecdote when he "found himself" blocking traffic:

We were trying to arrive at the square with a friend. We were very close to Taksim Square when the police drove us back with teargas. We were terribly gassed and beaten and we turned towards Kurtulus. We were very angry, I mean, 
we had to run away. We started to chant a slogan. There were just the two of us. All of a sudden, people started to applaud from their windows. They started clattering pots and pans and chant with us. We passed by Kurtulus street and turned to Tatavla street. There were some people there and we decided to block the traffic. I don't know why and how, we just felt confident all of a sudden, although we were just two. I don't know where this confidence came from. We blocked the traffic and people applauding us from their apartments started to join us. We were ten thousand within minutes! (Muzaffer, male, 62, activist in a network of leftist performance artists)

Gezi was a collective action of bodies who found themselves in situations that required immediate and almost inevitably risky solutions. Bodies on the streets in contentious protests like the Gezi mobilizations can be hit, hurt, even killed, just as the young woman quoted above rightfully expected: "I am pretty sure that they will open fire on us, I mean they will." The bodies on the streets were coughing, sneezing, and vomiting under a thick cloud of tear gas; they were bleeding and sweating bodies at risk of being killed or injured. Activists were there as flesh that could and indeed would be hurt. An anecdote from my field notes helps to depict the lived experience of bodily exposure in Gezi protests. I rushed to Taksim Square on the $3^{\text {rd }}$ of June. The police had already retreated from Taksim Square while clashes continued in Dolmabahce/Besiktas and Ankara. Thousands were in the square and Gezi Park and the number reached hundreds of thousands towards sunset. The crowd looked like one giant monster breathing in and out through oscillations of endlessly floating groups of people. A group was going towards Dolmabahce to clash with the police, while another group, this time of injured ones, approached Taksim Square to get medical help; there were mobile groups of health personnel with make-shift clinics around the square to help the injured.

Despite the great risk involved in participating in the Gezi movement, it had a positive, almost euphoric affective charge, which constitutes the fourth bodily axis of the mobilization. All Gezi accounts in the narrative interviews refer to feelings of happiness, solidarity, hope, and care. Life in the park had a transformative and healing effect on the participants. The Association of Psychologists for Social Solidarity, one of the organizations that actively participated in Gezi Park mobilization, stated in its report on the shifting psychological status of activists before and during the movement, that before the movement activists reported feelings of panic, fear, depression, alienation, pessimism, hopelessness, and insecurity. These negative emotions shifted to happiness, enthusiasm, excitement, hope, energy, peace, trust, and security within the park (TODAP, 2013). Feelings of optimism, joy and empowerment prevailed in the park. My field notes record that during one of the neighborhood assemblies in Kadıköy Yoğurtçu Park, an activist explained this by saying, "before Gezi Park, I was feeling disengaged from politics and kind of scared while passing in front of police officers in Taksim. But now I 
feel powerful. My shoulders are squared upon passing by the police officers now."

Most activists conveyed such highly positively-charged emotions about life in Gezi Park during the occupation. "I think there was a strange thing going on there, everyone was so understanding and caring towards one another, weirdly. I mean, you live together, you wake up together, go to bed together and you are neighbors of course... Somehow, everyone was living in harmony," said Zeynep (woman, 36, has loose connections with a socialist political party). The activists, when referring to their emotions and experiences in Gezi Park, kept saying that one needed to have been there to understand what they mean. They had trouble finding words to explain an embodied knowledge that is directly inscribed in the body.

In a narrative interview, an LGBT activist used the etymology of the word "peace" to explain this embodied experience that she describes as "contact":

Those days, I mostly felt like we were a body or an organism that moves and breathes together. With thousands of people... There was also something that we lacked in our daily lives. People were in contact with one another. I remember holding hands with many friends and walking like that in order not to get lost amongst the crowds. It was like that, we used to touch each other more, hug each other more. Personally, this contact made me feel so good, and the confidence that comes with it. On the other hand, everybody was in contact in other ways, as well. It was not only physical but also intellectual. Everyone was disclosing her own life and trying to understand the lives of others. Lastly, I learned that the word peace in Turkish, barış comes from the noun arrival and to make peace is to arrive, meaning that people go to others' houses. There was a peace in that sense. Of course, we did not live together, but everyone was in others' houses, in a constant visit. (İrem, queer, 29, LGBT activist)

Marxist-autonomous activist Sinem used the word "encounter" to explain this constant visit and mentioned the positively charged affections it created:

Different generations encountered each other, people who would otherwise never come together were together. It was true that people with Ocalan flags encountered people with Turkish flags. Do you remember that photo of a housewife standing right beside a gay activist? They were dancing together. The crowd was also hybrid, they were dancing to Balkan music. Normally, in our ordinary lives, also in classical political terms, we live so cautiously. There are codes determining the social relationships, you act accordingly, we are relating to one another always through these alienating codes. These codes were not there in Gezi. It was a process of taking our codes off. In our daily lives we are so harsh on one another. City life makes one a bully. In Gezi, in all moments, in the parks, behind the barricades, people were so caring. It is what the British people call "care." It was so great. Everyone was so caring! It was wonderful. You see that something you know from your own body becomes socialized. It was so amazing!" (Sinem, woman, 34)

Studies in Social Justice, Volume 12, Issue 1, 38-55, 2018 
As LGBT activist İrem states, "space is not space in itself, it is always there with respect to relations" and the process of making an alternative space also involves making an alternative relationality.

This affective atmosphere of inter-dependency among the protesters - what hooks (1990) calls a commonality of feeling - resulted in an "openness" with respect to the capacities of bodies to affect and be affected by one another. Issues previously deemed taboo, like the Kurdish problem or Armenian genocide, were openly discussed in park assemblies. Earthmeals, although religious iftar dinners, witnessed the participation of non-practicing Muslims and atheists, and LGBT and athiest activists made human chains in Gezi Park around Muslim protesters while they were collectively doing salaat (a religious practice performed five times a day). Feminists stated that their interventions contesting sexist language used during the first days of the protest (sexist swear words targeting women) had a positive impact on other protesters, especially on members of football teams' fan clubs who actually tried to stop using sexist swear words (Doğan, 2014). LGBT protesters stated that their grievances became highly visible and accepted within the Gezi Protests (Kaymak, 2014). The commonality of feeling created by the making of a community in its flesh and bones thus created an unprecedented moment in the political history of the country, when grievances of particular minorities, such as Kurds, Armenians, LGBTs, and feminists, actually affected larger populations swarming occupied spaces.

The activists frequently stated that "one needs to be there to understand" when referring to how they perceived life in Gezi Park. This signifies a bodily knowledge bound to this intertwined relationship between the production of space, practices of production and consumption and mechanisms of relationality. "There was a community being made there, a community was experiencing to inhale and exhale together - inhaling and exhaling together" (Özlem, woman, 27, member of the Revolutionary Anarchist Action (DAF)), as expressed by an anarchist activist in a narrative interview. The emphatically bodily language used by the activists to define the experience in the Gezi Movement also refers to the prevalence of this relationality. The LGBT activist İrem, in defining life there as a "carnival," reminded us of the etymological origin of the word in "carne," and underlines the significance of the "flesh" in the construction of a community: "it had a carnival-like atmosphere. Then, when we consider the etymology of the word, it comes from carne, flesh and makes you think of how one has a relationship with his own carne, the flesh of ceremonies and rituals."

The very construction of daily life in Gezi Park and the practice of communality in subsequent park assemblies were attempts to make a community in its flesh and bones. Gezi, which was a symbolic attempt to make an alternative communal space, was thus a movement where the flesh, the bodies with their basic requirements, fragility, interdependency and affections, came to the fore. Techniques and technologies, such as social 
media, were assembled in this flesh to find multiple solutions to the problems the activists tackled in this lived experience.

\section{Gezi Assemblages: Emergence as Embodiment}

The account provided above of the Gezi Movement evinces the pertinence of the growing attention to embodiment and materiality in recent social movements (Butler, 2011, 2014; Gregory, 2013; Happe, 2015; Perrugorría \& Tejerina, 2013; Protevi, 2015). Bodily aspects of social movements become even more significant to grasp collectivities in such movements, as the latter are situated at the intersection of material, corporeal, technological, technical, infrastructural and symbolic registers. As stated in the first section, assemblage signifies "a multiplicity which is made up of many heterogeneous terms and which establishes liaisons, relations across ages, sexes and reigns different natures" (Deleuze \& Parnet, 1987). Assemblage is relational, productive, heterogeneous, and finally desired (Müller, 2015, pp. 28-29). This emphasis on desire indicates that assemblages have a corporeal component, as "desire" is above all a bodily affect that "circulates throughout the assemblage" (Deleuze \& Guattari, 1980, p. 315).

I have deployed the concept of assemblage to account for two significant and inter-related aspects of the Gezi Movement: emergence of dissident communities through new arrangements and orderings of heterogeneous components; and the prevalence of bodily and affective encounters in occupied public space. I have argued that emergence of new dissident communities is above all a question of embodiment, the latter referring to the highly bodily aspects of such movements.

The concept of assemblage is already in use in social movement studies, mostly as an analytical tool to account for the heterogeneous arrangement of components of disparate natures (technological, technical, infrastructural, human, non-human etc.). Such an arrangement foregrounds emerging qualities of newly assembled contentious collectives. Hence, it is a useful theoretical tool to account for social transformation mobilized by the new social movements. Furthermore, assemblage serves as more than an analytical tool, by defining a certain type of contentious collective action governed by horizontality, heterogeneity, contagion and becoming. However, the bodily aspects of Occupy Movements are rarely explicated through the concept of assemblage. This article begins to rectify that oversight by drawing from accounts of the Gezi Movement that highlight bodily aspects of the mobilization and show how the emergence of new collectives goes hand in hand with their embodiment. The concept of assemblage conceptualizes emergence as embodiment, as it refers to a certain body politics characterized by the Spinozist conception of body that is defined through its affects. Emergence and transformation occur via "becoming other? than one is" (Bennett, 2005, p. 55), and "affects are becomings" (Deleuze and Guattari, 
1980, pp. 313-314) that "circulate and transform themselves throughout the assemblage" (p. 315). These multiple affective interactions, which I explicate in the previous section, define what a body can do. Social transformation mobilized by Occupy war-machines cannot be conceived without considerating the bodily experience with new relations to space, time, and one another. The concept of assemblage, and war-machine in particular, is a useful approach to the growing interest in the social movement studies literature to foreground bodily aspects of Occupy experiences.

\section{Acknowledgements}

Special thanks to Dr. Israel Rodriguez-Giralt, the supervisor of my PhD thesis on Gezi assemblages and CareNET research group of the Universitat Oberta de Catalunya (UOC). The article is composed as a result of the academic research conducted by the researcher with the funding of the Universitat Oberta de Catalunya as part of her $\mathrm{PhD}$ studies in the institution.

\section{References}

Bakıner, O. (2014). Can “the spirit of gezi” transform progressive politics in Turkey. In Ü. Özkırımlı (Ed.), The making of a protest movement in Turkey: \#occupygezi (pp. 65-76). Basingstoke, UK: Palgrave Macmillan.

Bassett, K. (2014). Ranciere, politics and the Occupy Movement. Environment and Planning D: Society and Space, 32(5), 886-901.

Berktay, F. (2014). Opening remarks. In Z. E. Güler (Ed.), New opportunities and impasses: Theorizing and experiencing politics (pp. 8-10). Istanbul, TR: Dakam Publishing.

Bennett, J. (2005). The agency of assemblages and the North American blackout. Public Culture, $17(3), 445-465$.

Butler, J. (2014a). Bodily vulnerability, coalitions and street politics. Critical Studies, 37(1), 99119.

Butler, J. (2014b). Foreword. In Ü. Özkırımlı (Eds.), The making of a protest movement in Turkey: \#occupygezi. (pp. vii- xvii). Basingstoke, UK: Palgrave Macmillan.

Butler, J. (2013). Exercising freedom (Interview with Judith Butler). Revolutions: Global trends \& Regional Issues, 1(1), 32-41.

Butler, J. (2011). Bodies in alliance and the politics of the street. European Institute for Progressive Cultural Policies, 9. Retrieved from http://www.eipcp.net/transversal/1011/butler/en

Castells, M. (2015). Networks of rage and hope: Social movements in the internet age. Cambridge: Polity Press. (Original work published 2012)

Chesters, G., \& Welsh, I. (2006). Complexity and social movements: Multiplicities at the edge of chaos. New York: Routledge.

Conio, A. (2015). Occupy: A people yet to come. London: Open Humanities Press.

DeLanda, M. (2006). A new philosophy of society: Assemblage theory and social complexity. London: Continuum.

Deleuze. G., \& Guattari, F. (1980). Milles plateaux: Capitalisme et schizophrenie 2. Paris: Editions de Minuit.

Deleuze, G., \& Parnet, C. (1987). Dialogues. New York: Columbia University Press.

Della Porta, D., \& Mattoni, A. (2014). Spreading protest: Social movements in times of crisis. UK: ECPR Press. 
Dikeç, M. (2017). Urban rage: The revolt of the excluded. Leicester, UK: Yale University Press.

Doğan, M. (2014, June 6). Kırmızıll, siyahlı, başörtülü, sapanli kadinlar. geziYorum çekiYorum Retrieved from http://geziyorum-cekiyorum.blogspot.com.es/2014/06/kufurle-degilinatla.html

D'Orsi, L. (2015). Crossing boundaries and reinventing futures: An ethnography of practices of dissent in Gezi Park. In G. Koç \& H. Aksu (Eds.), Another brick in the barricade: The Gezi resistance and its aftermath (pp. 16-34). Bremen, DE: Erscheinungsjahr.

Estralella, A., \& Jiménez, A. (2016). Matters of sense: Preoccupation in Madrid's popular assemblies movement. In A. Block \& I Farias (Eds.), Urban cosmopolitics: Agencements, assemblies, atmospheres (pp. 147-165). London: Routledge.

Farro, A., \& Demirhisar, D. (2014). The Gezi Park movement: A Turkish experience of the twenty-first century collective movements. International Review of Sociology, 24(1), 176189.

Gambetti, Z. (2014). Occupy Gezi as politics of the body. In Ü. Özkırımlı (Ed.), The making of a protest movement in Turkey: \#occupygezi (pp. 89-102). Basingstoke, UK: Palgrave Macmillan.

Gerbaudo, P. (2012). Tweets and streets: Social media and contemporary activism. London: Pluto Books.

Gregory, D. (2013). Tahrir: Politics, publics and performances of space. Middle East Critique, 22(3), 235-246.

Happe, K. (2015). Parrhēsia, biopolitics and Occupy. Philosophy \& Rhetoric, 48(2), 211-223.

hooks, b. (1990). Yearning: race, gender and cultural politics. Cambridge, MA: South End Press.

Ingold, T. (2011). Being alive: Essays on movement, knowledge and description. London: Routledge.

Ingold, T. (2007). Line: A brief history. London: Routledge.

Juris, J. (2012). Reflections on \#occupy everywhere: Social media, public space and emerging logics of aggregation. American Ethnologist, 39(2), 259-279.

Juris, J. (2008). Networking futures: The movements against corporate globalization. Durham, NC: Duke University Press.

Kaymak, Ö. (2014, May 31). Toplumsal hareketler ve gezi direnişi. Biamag Cumartesi. Retrieved from http://bianet.org/biamag/siyaset/156089-toplumsal-hareketler-ve-gezidirenisi

Koç, G., \& Aksu, H. (2015). The Gezi resistance and its aftermath. Bremen, DE: Erscheinungsort.

Kuyumlu, M. (2013). Reclaiming the right to the city: Reflections on the urban uprisings in Turkey, City, 17(3), 274-278.

Lockie, S. (2004). Collective agency, non-human causality and environmental social movements. Journal of Sociology, 40(1), 41-58.

McFarlane, C. (2009). Translocal assemblages: Space, power and social movements. GeoForum, $40,561-567$.

Müller, M. (2015). Assemblages and actor-networks: Rethinking socio-material power, politics and space. Geography Compass, 9(1), 27-41.

Nail, T. (2017). What is an assemblage? SubStance, 46(1), 21-37.

Özel, S. (2014). A moment of elation: The Gezi protests/resistance and the fading of the AKP project. In Ü. Özkırımlı (Ed.), The making of a protest movement in Turkey: \#occupygezi (pp. 7-24). Basingstoke, UK: Palgrave Macmillan.

Özkaynak, B., Aydın, C. İ., Ertör-Akyazı, P., \& Ertör, I. (2015). The Gezi Park resistance from an environmental justice and social metabolism perspective. Capitalism Nature Socialism, 26(1), 99-114.

Perrugorría, I., \& Tejerina, B. (2013). Politics of the encounter: Cognition, emotions and networks in the Spanish 15M. Current Sociology 61(4), 424-442.

Protevi, J. (2015). Semantic, pragmatic and affective enactment in Occupy Wall Street. In A. Conio (Ed.), Occupy: A people yet to come (pp. 88-97). London: Open Humanities Press,

Protevi, J. (2009). Political affect: Connecting the social and the somatic. Minneapolis, MN: University of Minnesota Press.

Razsa, M., \& Kurnik, A. (2012). The Occupy Movement in Zizek's hometown: Direct democracy

Studies in Social Justice, Volume 12, Issue 1, 38-55, 2018 
and a politics of becoming. American Ethnologist. 89(2), 238-258.

Rodriguez-Giralt, I. (2015). Birds as lines: The production of alternative regimes of environmental management in the aftermath of a toxic disaster. Geoforum 66, 156-166.

Rodriguez-Giralt, I. (2011). Social movements as actor-networks: Prospects from a symmetrical approach to Donana's environmentalist protests. Convergencia, 56, pp. 13-35.

Rodriguez-Giralt, I., \& Marrero-Guillamón, I. (2018). Reassembling activism, activating assemblages: An introduction. Social Movement Studies Journal, 17(3), 1-24.

Sibertin-Blanc, G. (2013). Politique et etat chez Deleuze et Guattari: Essai sur le matérialisme historico-machinique. Paris: PUF.

Stengers, I., \& Pignarre, P. (2005). La Sorcellerie Capitaliste. Paris: Editions Decouvert.

TODAP. (2013, September 22). Direnişten Önce ve Sonra Ruh Halleri - Atölye Raporu Sunumu. TODAP. Retrieved from http://todap.org/bolum_detay.aspx?yaziId=1370\&bolumId=2

Tejerina, B., Perugorria, I., Benski, T., Langman, L. (2013). 'From indignation to occupation: a new wave of global mobilization.' Current Sociology, 61(4), 377-392.

Tuğal, C. (2013). "Resistance everywhere": The Gezi revolt in global Perspective. New perspectives on Turkey, 49, 157-172.

Vatikiosis, A., \& Yörük, M. (2016). Gezi movement and the networked public sphere: A comparative analysis in global contect. Social Media + Society, 2(3), 2056305116662184

Yörük, E., \& Yüksel, M. (2014). Class and politics in Turkey's Gezi protests. New Left Review, $89,103-123$. 